\title{
Pengembangan Epistemologi Positivisme Dalam Memahami Konsep Menghitung Keliling Dan Luas Lingkaran Di MI Muhammadiyah Kebutuh Kecamatan Bukateja Kabupaten Purbalingga
}

\author{
${ }^{\mathbf{1}}$ Khabib Khamaludin, ${ }^{\mathbf{2}}$ Abdul Wachid \\ ${ }^{1}$ Mahasiswa Prodi Pendidikan Guru Madrasah Ibtidaiyah Pascasarjana, IAIN Purwokerto \\ ${ }^{2}$ Dosen/ Pendidikan Guru Madrasah Ibtidaiyah Pascasarjana, IAIN Purwokerto \\ 1201763008@mhs.iainpurwokerto.co.id, ${ }^{2}$ abdulwachidbs@iainpurwokerto.ac.id
}

\begin{abstract}
Abstrack. This study aims to develop philosophy learning tools through positivism epistemology in understanding the concept of calculating the circumference and area of a circle. This research was conducted in MI Muhammadiyah Kebutuh,Kec. Bukateja Kab. Purbalingga. This type of research is a qualitative descriptive field research. Data collection methods used are observation, interview, and documentation methods. Based on the research results, in general the epistemology of positivism can provide an understanding of the scientific method and base some knowledge on the principle of verification, especially on the material of calculating the circumference and area of a circle. Given that mathematics is an exact science that produces a knowledge in which humans will be able to explain the reality of life not speculatively, but concretely, certainty and can be absolute, orderly and valid.
\end{abstract}

Keywords: Development of the Epistemology of Positivism, the Concept of Circling a Circle, MI Muhammadiyah Kebutuh Purbalingga

Abstrak. Penelitian ini bertujuan untuk mengembangkan perangkat pembelajaran filsafat melalui epistemologi positivisme dalam memahami konsep menghitung keliling dan luas lingkaran. Penelitian ini dilaksanakan di MI Muhammadiyah Kebutuh, Kec. Bukateja Kab. Purbalingga. Jenis penelitian yang digunakan adalah penelitian lapangan yang bersifat deskriptif kualitatif. Metode pengumpulan data yang digunakan adalah metode observasi, wawancara, dan dokumentasi. Berdasarkan hasil penelitian, secara garis besar epistemologi positivisme dapat memberikan pemahaman pada metode ilmiah dan mendasarkan sesuatu pengetahuan atas prinsip verifikasi, khususnya pada materi menghitung keliling dan luas lingkaran. Mengingat matematika adalah ilmu pasti yang menghasilkan suatu pengetahuan yang mana manusia akan mempu menjelaskan realitas kehidupan tidak secara spekulatif, melainkan konkrit, pasti dan bisa jadi mutlak, teratur dan valid.

Kata kunci: Pengembangan Epistemologi Positivisme, Konsep Keliling Lingkaran, MI Muhammadiyah Kebutuh Purbalingga

\section{PENDAHULUAN}

Manusia pada dasarnya adalah makhluk pencari kebenaran. Manusia tidak pernah puas dengan apa yang sudah ada, tetapi selalu mencari dan mencari kebenaran yang sesungguhnya dengan bertanya-tanya untuk mendapatkan jawaban. Namun setiap jawaban-jawaban tersebut juga belum tentu memuaskan manusia. Ia harus mengujinya dengan metode tertentu untuk mengukur apakah yang dimaksud disini bukanlah kebenaran yang bersifat semu, tetapi kebenaran yang bersifat ilmiah yaitu kebenaran yang bisa diukur dengan cara-cara ilmiah.

Perkembangan pengetahuan yang semakin pesat sekarang ini, tidaklah menjadikan manusia berhenti untuk mencari kebenaran. Justru sebaliknya, semakin menggiatkan manusia untuk terus mencari dan mencari kebenaran yang berlandaskan teoriteori yang sudah ada sebelumnya untuk menguji sesuatu teori baru atau menggugurkan teori sebelumnya. Sehingga manusia sekarang lebih giat lagi melakukan penelitian-penelitian yang bersifat ilmiah untuk mencari solusi dari setiap permasalahan yang dihadapinya. Karena itu bersifat statis, tidak kaku, artinya ia tidak akan berhenti pada satu titik, tapi akan terus berlangsung seiring dengan waktu manusia dalam memenuhi rasa keingintahuannya terhadap dunia.

Untuk itulah setiap manusia harus dapat berfikir filosofis dalam menghadapi segala realitas kehidupan ini yang menjadikan filsafat harus dipelajari. Filsafat merupakan sebuah disiplin ilmu yang terkait dengan perihal kebijaksanaan. Kebijaksanaan merupakan titik 
ideal dalam kehidupan manusia, karena ia dapat menjadikan manusia untuk bersikap dan bertindak atas dasar pertimbangan kemanusiaan yang tinggi (actus humanus), bukan asal bertindak sabagaimana yang biasa dilakukan manusia (actus homoni). Kebijaksanaan tidaklah dapat dicapai dengan jalan biasa, ia memerlukan langkah-langkah tertentu, khusus, istimewa. Beberapa langkah menuju kearah kebijaksanaan itu antara lain: 1) membiasakan diri untuk bersikap kritis terhadap kepercayaan dan sikap yang selama ini sangat kita junjung tinggi, 2) Berusaha untuk memadukan (sintesis) hasil bermacammacam sains dan pengalaman kemanusian, sehingga menjadi pandangan yang konsisten tentang alam semesta beserta isinya, 3) mempelajari dan mencermati jalan pemikiran para filsuf dan meletakkannya sebagai pisau analisis untuk memecahkan masalah kehidupan yang berkembang dalam kehidupan konkrit, sejauh pemikiran itu memang relevan dengan situasi yang kita hadapi, 4) menelusuri hikmah yang terkandung dalam ajaran agama, sebab agama merupakan sumber kebijaksanaan hidup manusia (Rizal $\mathrm{M}$. 2001:1-2).

Pendidikan Nasional yang bertujuan untuk berkembangnya potensi peserta didik agar menjadi manusia yang beriman dan bertakwa kepada Tuhan Yang Maha Esa, berakhlak mulia, sehat, berilmu, cakap, kreatif, mandiri, dan menjadi warga negara yang demokratis serta bertanggung jawab (UU RI No. 20 Th. 2003). Tujuan ini dituangkan dalam tujuan pembelajaran matematika yaitu melatih cara berfikir dan bernalar, mengembangkan aktifitas kreatif, mengembangkan kemampuan memecahkan masalah, mengembangkan kemampuan menyampaikan infomasi atau mengkomunikasikan gagasan. Sehingga matematika merupakan bidang ilmu yang strategis untuk membentuk generasi yang siap menghadapi era global yang penuh dengan kompetitif tersebut.

Pembelajaran Matematika merupakan pembelajaran yang sangat penting bagi anak, karena dalam kehidupan nyata bermasyarakat nanti setelah dewasa, matematika akan selalu digunakan dalam segala aspek kehidupan, untuk itu, keberhasilan pembelajaran matematika siswa menjadi hal yang sangat penting dan mutlak harus dicapai. Matematika merupakan salah satu cabang dari sekian banyak ilmu yang sistematis, teratur dan eksak. Matematika juga merupakan ilmu pengetahuan mengenai logika dan problem-problem numerik, matematika membahas fakta-fakta dan hubungan-hubungannya, serta membahas problem ruang dan waktu. Mata Pelajaran Matematika perlu diberikan kepada semua peserta didik dari tingkat pra sekolah (TK), sekolah dasar sampai pada perguruan Tinggi untuk membekali mereka dengan kemampuan berfikir logis, analitis, sistematis, kritis, kreatif serta mampu bekerja sama.

Geometri merupakan salah satu cabang matematika yang sangat penting sebagai ilmu dasar dan sudah dikenal anak-anak sejak kecil. Geometri telah dipelajari pada jenjang pendidikan dasar, pendidikan sekolah menengah, sampai pendidikan tinggi. Geometri didefinisikan sebagai cabang matematika yang mempelajari tentang titik, garis, bidang, dan benda-benda ruang serta sifat-sifatnya, ukuran-ukurannya, dan hubungannya satu sama lain.

Oleh karena itu sebagai seorang pendidik harus mau tahu akan kebutuhan anak didik, terutama dalam pelayanan dan penyampaian materi pelajaran. Sehingga sangatlah perlu sebagai pendidik memahami konsep dasar kegiatan pengajarannya, agar lebih tepat untuk menyampaikan materi supaya hasil proses belajar mengajar berhasil maksimal. Dan mampu menghasilkan pemahaman berupa pengalaman-pengalaman obyektif.

Dari kondisi tersebut menjadi latar belakang peneliti untuk mengkaji bagaimana pengembangan epistemologi positivisme dalam memahami konsep menghitung keliling dan luas lingkaran di MI Muhammadiyah Kebutuh, Kec. Bukateja Kab. Purbalingga yang akan dituangkan dalam sebuah jurnal berjudul "Pengembangan Epistemologi Positivisme dalam Memahami Konsep Menghitung Keliling Lingkaran di MI Muhammadiyah Kebutuh Kec. Bukateja Kab. Purbalingga". Kajian tentang bagaimana manusia memperoleh pengetahuan dan apakah 
sarana yang paling memadai untuk mencapai pengetahuan yang benar, serta apa yang dimaksud dengan kebenaran itu sendiri.

\section{METODE PENELITIAN}

Jenis penelitian yang digunakan pada penelitian ini adalah penelitian lapangan (field research), karena peneliti harus terjun langsung ke lapangan (lokasi) untuk membaca, memahami, dan mempelajari situasi bagaimana proses pengembangan epistemologi positifisme. Dalam penelitian lapangan yang digunakan, penulis dapat menganalisis teori-teori yang sudah ditentukan sehingga data yang diperoleh di lapangan tersusun dengan rapi. Hasil dari penelitian diperoleh dari komunikasi dengan subyek penelitian serta hasil observasi, wawancara, dan dokumentasi. Sedangkan data yang diperoleh merupakan kata-kata yang dideskripsikan dan diinterpretasikan. Pendekatan dalam penelitian ini adalah deskriptif kualitatif. Ditunjukan untuk mendeskripsikan fenomena, fenomena yang ada, baik fenomena yang besifat alamiah ataupun yang bersifat rekayasa manusia. Penelitian deskriptif adalah penelitian yang diarahkan untuk memberikan gejala-gejala, fakta-fakta atau kejadian-kejadian secara sistematis dan akurat, mengenai sifat-sifat populasi atau daerah tertentu.

Dalam pelaksaan untuk mengembangkan dan mengetahui konsep lingkaran yaitu mencari luas lingkaran dan keliling lingkaran, peserta didik dapat diajak untuk mencari keliling benda benda yang berbentuk lingkaran yang ada sekitarnya.

\section{HASIL DAN PEMBAHASAN \\ Pengertian Epistemologi Positivisme}

Pengembangan berasal dari kata kembang yang berarti membesar. Dalam Kamus Besar Bahasa Indonesia, Pengembangan berarti perbuatan mengembangkan. Pengembangan menurut Morris adalah upaya memperluas atau mewujudkan potentsi-potensi, membawa suatu keadaan secara bertingkat kepada keradaan yang lengkap, lebih besar, atau lebih baik, memajukan sesuatu yang lebih awal kepada yang lebih akhir atau dari sederhana menjadi lebih kompleks.

Dari berbagai pendapat para ahli tersebut, dapat disimpulkan, pengembangan adalah usaha, cara, atau proses yang dilakukan untuk menumbuhkan sesuatu yang dimiliki seseorang menjadi lebih baik atau lebih kompleks.

Pengetahuan dalam filsafat dibahas dalam epistemologi. Usaha manusia untuk mencari pengetahuan yang bersifat mutlak dan pasti telah berlangsung terus menerus dengan penuh semangat, seperti rasionalisme, empirisme ataupun yang lainnya. Walaupun begitu, paling tidak sejak zaman Aristoteles, terdapat tradisi epistemologi yang kuat untuk mendasarkan diri pada pengalaman manusia dan meninggalkan cita-cita untuk mencari pengetahuan yang mutlak tersebut.

Menurut Poespoprodjo dalam Logika Scientifika, kewajiban mencari kebenaran adalah tuntutan intrinsik manusia untuk merealisasikan manusia menurut tuntutan keluhuran keinsaniannya. Manusia dikaruniai akal budi yang membedakannya dari makhluk hidup yang lain. Dengan akal budi ini manusia berpikir. Pada dasarnya berpikir merupakan sebuah proses yang membuahkan pengetahuan. Pengetahuan itu sendiri merupakan obor bagi peradaban manusia dimana manusia menemukan dirinya dan menghayati hidup dengan lebih sempurna (W. Poespoprodjo, 1999: 61).

Setelah era kaum rasionalisme yang dipelopori oleh Rene Descartes, muncullah sebuah aliran empirisme. Empirisme itu sendiri pada abad ke-19 dan 20 mereka lebih mengikuti jejak Francis Bacon yang memberi tekanan kepada empirik atau pengalaman sebagai sumber pengenalan. Akan tetapi ini tidak berarti bahwa rasionalisme sama sekali ditolak. Dapat dikatakan, bahwa rasionalisme digunakan dalam rangka empirisme, atau rasionalisme dilihat dalam rangka empirisme (Harun H, 1999: 31-32).

Dalam sejarah perkembangannya empirisme menjadi beberapa aliran yang berbeda, yaitu Positivisme, Materialisme, dan Pragmatisme. Dalam makalah ini akan dibahas tentang seluk beluk positivisme dan penilaian 
atas implikasinya. Positivisme berkaitan langsung dengan perkembangan pola fikir manusia dan ilmu pengetahuan yang lebih kita kenal dengan istilah epistemologi positivisme.

Istilah positivisme pertama kali digunakan oleh Saint Simon (sekitar tahun 1825 M.), jikalau kita melihat lebih lanjut, maka dapat kita katakan bahwa positivisme merupakan kelanjutan dari empirisme. Prinsip filosofik tentang positivisme pertama kali dikembangkan oleh seorang empiris Inggris yang bernama Francis Bacon (sekitar tahun 1600 M.).

Pada abad ke-19 timbullah filsafat yang disebut Positivisme, yang diturunkan dari kata - positif\|. Filsafat ini berpangkal dari apa yang telah diketahui, yang faktual, yang positif. Oleh karena itu metafisika ditolak. Apa yang kita ketahui secara positif adalah segalah yang tampak, segala gejala. Demikian Positivisme membatasi filsafat dan ilmu pengetahuan kepada bidang gejala-gejala. Apa yang dapat kita lakukan ialah segala fakta, yang menyajikan kepada kita sebagai penampakan atau gejala, kita terima seperti apa adanya.

Sesudah itu kita berusaha untuk mengatur fakta-fakta tadi menurut hukum tertentu, akhirnya dengan berpangkal kepada hukum-hukum yang telah ditemukan tadi kita mencoba melihat ke masa depan, apa yang akan tampak sebagai gejala dan menyesuaikan diri dengannya. Arti segala ilmu pengetahuan ialah mengetahui untuk dapat melihat ke masa depan. Jadi kita hanya dapat menyatakan fakta-faktanya, dan menyelidiki hubunganhubungannya yang satu dengan yang lain. Maka tiada gunanya untuk menanyakan kepada hakekat atau sebab-sebab yang sebenarnya dari gejala-gejala itu. Yang harus diusahakan orang ialah menentukan syaratsyarat di mana menurut persamaannya dan urutannya. Hubungan yang tetap yang tampak dalam persamaan itu disebut - pengertian\|, sedangkan hubungan-hubungan tetap yang tampak pada urutannya disebut -hukumhukum $\|$ (Harun H, 1999: 110).

Pengertian dari sudut sumbernya ada dua macam (Mudlor A, 1994: 47).

1. Pengertian a priori
Pengertian yang sudah ada sebelum pengalaman. Jenis pengertian ini merupakan bawaan sejak lahir. Al Ghazali menamakan sebagai ilmu auwali atau ilmu dharuri.

2. Pengertian a posteriori

Pengertian yang baru ada setelah pengalaman. Jenis pengertian ini merupakan hasil pengamatan terhadap sesuatu. Al Ghazali menamakannya sebagai ilmu nadhari atau ilmu muktasab.

Untuk membedakan keduanya, dapat dilihat contoh berikut ini, rasa hormat ada pada setiap manusia adalah sebagai pengertian a priori, tetapi cara menghormati yang perlu dipelajari adalah sebagai pegertian a posteriori. Sebagaimana yang diketahui, cara hormat itu beragam. Inilah yang membedakan antara positivisme dan empirisme, positivisme hanya membatasi diri pada pengalaman-pengalaman objektif, sedangkan empirisme menerima juga pengalaman-pengalaman batiniah atau pengalaman yang subyektif. Kesamaan keduannya mengutamakan pengalaman.

Filsafat positivisme diantarkan oleh Auguste Comte (1798-1857). Ia belajar di sekolah politeknik di Paris, tetapi ia dikeluarkan kerena ia seorang pendukung republik, sedangkan sekolahnya justru sangat royalistis. Comte menjadi juru tulis pada de Saint Simon. Kebanyakan idenya memang berasal dari de Saint-Simon (Harri H, 1992: 54).

Filsafat positivisme merupakan salah satu aliran filsafat modern yang lahir pada abad ke-19. Dasar-dasar filsafat ini dibangun oleh Saint Simon dan dikembangkan oleh Auguste Comte. Adapun yang menjadi tititk tolak dari pemikiran positivis ini adalah, apa yang telah diketahui adalah yang faktual dan positif, sehingga metafisika ditolaknya. Di sini, yang dimaksud dengan — positif\| adalah segala gejala yang tampak seperti apa adanya, sebatas pengalaman-pengalaman obyektif. Jadi, setelah fakta diperoleh, fakta-fakta tersebut diatur sedemikian rupa agar dapat memberikan semacam asumsi (proyeksi) ke masa depan (Asmoro A, 2001: 116).

Sebenarnya, tokoh-tokoh aliran ini sangat banyak. Namun begitu, Auguste Comte dapat dikatakan merupakan tokoh terpenting 
dari aliran filsafat Positivisme. Menurut Comte, dan juga para penganut aliran positivisme, ilmu pengetahuan tidak boleh melebihi fakta-fakta karena positivisme menolak metafisisme. Bagi Comte, menanyakan hakekat benda-benda atau penyebab yang sebenarnya tidaklah mempunyai arti apapun. Oleh karenanya, ilmu pengetahuan dan juga filsafat hanya menyelidiki fakta-fakta dan hubungan yang terdapat antara fakta-fakta. Dengan demikian, kaum positivis membatasi dunia pada hal-hal yang bisa dilihat, diukur, dianalisa dan yang dapat dibuktikan kebenarannya (Koento W, 1996: 17).

Manusia harus menyelidiki gejala-gejala dan hubungan-hubungan antara gejala-gejala ini supaya ia dapat meramalkan apa yang akan terjadi. Tidak ada gunanya untuk mencari hakekat kenyataan. Hanya satu hal yang penting, mengetahui, supaya siap untuk bertindak, mengetahui supaya manusia dapat menantikan apa akan terjadi. Lawan filsafat positif itu bukanlah suatu filsafat negatif, melainkan filsafat spekulatif atau metafisika.

\section{Tahap Teologis}

Pada tahap teologis ini, manusia percaya bahwa dibelakang gejala-gejala alam terdapat kuasa-kuasa adikodrati yang mengatur fungsi dan gerak gejala-gejala tersebut. Kuasa-kuasa ini dianggap sebagai makhluk yang memiliki rasio dan kehendak seperti manusia. Tetapi orang percaya bahwa mereka berada pada tingkatan lebih tinggi dari pada makhlukmakhluk selain insani.

Pada taraf pemikiran ini terdapat lagi tiga tahap. Pertama, tahap yang paling bersahaja atau primitif, dimana orang menganggap bahwa segala benda berjiwa (animisme). Kedua, tahap ketika orang menurunkan kelompok hal-hal tertentu, di mana seluruhnya diturunkan dari suatu kekuatan adikodrati yang melatarbelakanginya sedemikian rupa hingga tiap tahapan gejala-gejala memiliki dewa sendiri-sendiri (polytheisme). Gejala-gejala - sucill dapat disebut -dewa-dewall, dan -dewa-dewall ini dapat diatur dalam suatu sistem, sehingga menjadi politeisme dengan spesialisasi. Ada dewa api, dewa lautan, dewa angin, dan seterusnya. Ketiga, adalah tahapan tertinggi, di mana pada tahap ini orang mengganti dewa yang bermacam-macam itu dengan satu tokoh tertinggi (esa), yaitu dalam monotheisme (Koento W, 1996: 27).

Singkatnya, pada tahap ini manusia mengarahkan pandangannya kepada hakekat yang batiniah (sebab pertama). Di sini, manusia percaya kepada kemungkinan adanya sesuatu yang mutlak. Artinya, di balik setiap kejadian tersirat adanya maksud tertentu (Asmoro A, 2001: 117).

\section{Tahap Metafisik}

Tahap ini bisa juga disebut sebagai tahap transisi dari pemikiran Comte. Tahapan ini sebenarnya hanya merupakan varian dari cara berpikir teologis, karena di dalam tahap ini dewa-dewa hanya diganti dengan kekuatankekuatan abstrak, dengan pengertian atau dengan benda-benda lahiriah, yang kemudian dipersatukan dalam sesuatu yang bersifat umum, yang disebut dengan alam. Terjemahan metafisis dari monoteisme itu misalnya terdapat dalam pendapat bahwa semua kekuatan kosmis dapat disimpulkan dalam konsep -alam\|, sebagai asal mula semua gejala (Koento W, 1996: 17).

\section{Tahap Positif}

Pada tahap positif, orang tahu bahwa tiada gunanya lagi untuk berusaha mencapai pengenalan atau pengetahuan yang mutlak, baik pengenalan teologis maupun metafisik. Ia tidak lagi mau mencari asal dan tujuan terakhir seluruh alam semesta ini, atau melacak hakekat yang sejati dari - segala sesuatul yang berada di belakang segala sesuatu. Sekarang orang berusaha menemukan hukumhukum kesamaan dan urutan yang terdapat pada fakta-fakta yang disajikan kepadanya, yaitu dengan - pengamatanl dan dengan -memakai akalnyall. Pada tahap ini pengertian -menerangkan $\|$ berarti fakta-fakta yang khusus dihubungkan dengan suatu fakta umum. Dengan demikian, tujuan tertinggi dari tahap positif ini adalah menyusun dan mengatur segala gejala di bawah satu fakta yang umum (Harun H, 1999: 111).

Bagi Comte, ketiga tahapan tersebut tidak hanya berlaku bagi perkembangan rohani seluruh umat manusia, tetapi juga berlaku bagi di bidang ilmu pengetahuan. Dalam hal ini, 
Comte menerangkan bahwa segala ilmu pengetahuan semula dikuasai oleh pengertianpengertian teologis, sesudah itu dikacaukan dengan pemikiran metafisis dan akhirnya dipengaruhi hukum positif. Jelasnya, ketiga tahapan perkembangan umat manusia itu tidak saja berlaku bagi suatu bangsa atau suku tertentu, akan tetapi juga individu dan ilmu pengetahuan.

Meskipun seluruh ilmu pengetahuan tersebut dalam perkembangannya melalui ketiga macam tahapan tersebut, namun bukan berarti dalam waktu yang bersamaan. Hal demikian dikarenakan segalanya tergantung pada kompleksitas susunan suatu bidang ilmu pengetahuan. Semakin kompleks susunan suatu bidang ilmu pengetahuan tertentu, maka semakin lambat mencapai tahap ketiga.

Lebih jauh Comte berpendapat bahwa pengetahuan positif merupakan puncak pengetahuan manusia yang disebutnya sebagai pengetahuan ilmiah. Di sini, ilmu pengetahuan dapat dikatakan bersifat positif apabila ilmu pengetahuan tersebut memusatkan perhatian pada gejala-gejala yang nyata dan kongkrit. Dengan demikian, maka ada kemungkinan untuk memberikan penilaian terhadap berbagai cabang ilmu pengetahuan dengan jalan mengukur isinya yang positif, serta sampai sejauh mana ilmu pengetahuan tersebut dapat mengungkapkan kebenaran yang positif (Bernard D, 1992: 67). Sesuai dengan pandangan tersebut kebenaran metafisik yang diperoleh dalam metafisika ditolak, karena kebenarannya sulit dibuktikan dalam kenyataan.

Demikianlah pandangan Auguste Comte tentang hukum tiga tahapnya, yang pada intinya menyatakan bahwa pemikiran tiap manusia, tiap ilmu dan suku bangsa melalui 3 tahap, yaitu teologis, metafisis dan positif ilmiah. Dalam hal ini Auguste Comte memberikan analog manusia muda atau sukusuku primitif pada tahap teologis sehingga dibutuhkan figur dewa-dewa untuk -menerangkan\| kenyataan. Meningkat remaja dan mulai dewasa dipakai prinsipprinsip abstrak dan metafisis. Pada tahap dewasa dan matang digunakan metode-metode positif dan ilmiah.
Positivisme melembagakan pandangan dunia objetivistiknya dalam suatu doktrin kesatuan ilmu. Doktrin kesatuan ilmu mengatakan bahwa seluruh ilmu, baik ilmu alam maupun manusia, harus berada di bawah payung paradigma positivistik. Doktrin kesatuan ilmu mengajukan kriteria-kriteria bagi ilmu pengetahuan sebagai berikut: (http://id.Filsafat-positivisme-dan-ciricirinya_files)

1. Bebas nilai, pengamat harus bebas dari kepentingan, nilai, emosi dalam mengamati objeknya agar diperoleh pengetahuan yang objektif.

2. Ilmu pengetahuan harus menggunakan metode verifikasi-empiris.

3. Bahasa yang digunakan harus; analitik (bisa dibenarkan atau disahkan secara logis), bisa diperiksa secara empiris dan atau nonsense.

4. Bersifat eksplanasi, ilmu pengetahuan hanya diperbolehkan melakukan penjelasan akan keteraturan yang ada di alam semesta, ia hanya menjawab pertanyaan how dan tidak menjawab pertanyaan why.

Positivisme menjadi dogma epistemik dengan mengklaim bahwa ilmu pengetahuan harus mengikuti doktrin unified science apabila ingin disebut ilmu pengetahuan ilmiah, bukan semata-mata pengetahuan sehari-hari praktis eksistensial.

1. Objektif/bebas nilai. Dikotomi yang tegas antara fakta dan nilai mengharuskan subjek peneliti mengambil jarak dari realitas dengan bersikap bebas nilai. Hanya melalui fakta-fakta yang teramati dan terukur, maka pengetahuan kita tersusun dan menjadi cermin dari realitas (korespondensi).

2. Fenomenalisme, tesis bahwa realitas terdiri dari impresi-impresi. Ilmu pengetahuan hanya berbicara tentang realitas berupa impresi-impresi tersebut. Substansi metafisis yang diandaikan berada di belakang gejala-gejala penampakan ditolak (antimetafisika).

3. Nominalisme, bagi positivisme hanya konsep yang mewakili realitas partikularlah yang nyata.

4. Reduksionisme, realitas direduksi menjadi fakta-fakta yang dapat diamati. 
5. Naturalisme, tesis tentang keteraturan peristiwa-peristiwa di alam semesta yang meniadakan penjelasan supranatural (adikodrati). Alam semesta memiliki strukturnya sendiri dan mengasalkan strukturnya sendiri.

6. Mekanisme, tesis bahwa semua gejala dapat dijelaskan dengan prinsip-prinsip yang dapat digunakan untuk menjelaskan mesinmesin (sistem-sistem mekanis). Alam semesta diibaratkan sebagai giant clock work (http://id.Filsafat-positivisme-danciri-cirinya_files).

\section{Kelebihan Positivisme}

Diantara kelebihan positivisme adalah:

1. Positivisme lahir dari faham empirisme dan rasional, sehingga kadar dari faham ini jauh lebih tinggi dari pada kedua faham tersebut.

2. Hasil dari rangkaian tahapan yang ada didalamnya, maka akan menghasilkan suatu pengetahuan yang mana manusia akan mempu menjelaskan realitas kehidupan tidak secara spekulatif, arbitrary, melainkan konkrit, pasti dan bisa jadi mutlak, teratur dan valid.

3. Dengan kemajuan dan dengan semangat optimisme, orang akan didorong untuk bertindak aktif dan kreatif, dalam artian tidak hanya terbatas menghimpun fakta, tetapi juga meramalkan masa depannya.

4. Positivisme telah mampu mendorong lajunya kemajuan disektor fisik dan teknologi.

5. Positivisme sangat menekankan aspek rasionali-ilmiah, baik pada epistemology ataupun keyakinan ontologik yang dipergunakan sebagai dasar pemikirannya.

\section{Kelemahan Positivisme}

Diantara kelemahan positivisme adalah:

1. Analisis biologik yang ditransformasikan ke dalam analisis sosial dinilai sebagai akar terpuruknya nilai-nilai spiritual dan bahkan nilai-nilai kemanusiaan. Hal ini dikarenakan manusia tereduksi ke dalam pengertian fisik-biologik.

2. Akibat dari ketidakpercayaannya terhadap sesuatu yang tidak dapat diuji kebenarannya, maka faham ini akan mengakibatkan banyaknya manusia yang nantinya tidak percaya kepada Tuhan,
Malaikat, Setan, surga dan neraka. Padahal yang demikian itu didalam ajaran Agama adalah benar kebenarannya dan keberadaannya. Hal ini ditandai pada saat paham positivisme berkembang pada abad ke 19, jumlah orang yang tidak percaya kepada agama semakin meningkat.

3. Manusia akan kehilangan makna, seni atau keindahan, sehingga manusia tidak dapat merasa bahagia dan kesenangan itu tidak ada. Karena dalam positivisme semua hal itu dinafikan.

4. Hanya berhenti pada sesuatu yang nampak dan empiris sehingga tidak dapat menemukan pengetahuan yang valid.

5. Positivisme pada kenyataannya menitik beratkan pada sesuatu yang nampak yang dapat dijadikan obyek kajiaannya, di mana hal tersebut adalah bergantung kepada panca indera. Padahal perlu diketahui bahwa panca indera manusia adalah terbatas dan tidak sempurna. Sehingga kajiannya terbatas pada hal-hal yang nampak saja, padahal banyak hal yang tidak nampak dapat dijadikan bahan kajian.

6. Hukum tiga tahap yang diperkenalkan Comte mengesankan dia sebagai teorisi yang optimis, tetapi juga terkesan lincar seakan setiap tahapan sejarah evolusi merupakan batu pijakan untuk mencapai tahapan berikutnya, untuk kemudian bermuara pada puncak yang digambarkan sebagai masyarakat positivisme. Bias teoritik seperti itu tidak memberikan ruang bagi realitas yang berkembang atas dasar siklus - yakni realitas sejarah berlangsung berulang-ulang tanpa titik akhir sebuah tujuan sejarah yang final.

\section{Mata Pelajaran Matematika \\ Pengertian Mata pelajaran Matematika}

Dalam kurikulum pendidikan dasar dan menengah wajib memuat: Pendidikan Agama, Pendidikan Kewarganegaraan, Bahasa Indonesia, Matematika, Ilmu Pengetahuan Alam, Ilmu Pengetahuan Sosial, Seni dan Budaya, Pendidikan Jasmani dan Olahraga, Ketrampilan/Kejujuran dan Muatan Lokal. Dengan demikian Matematika merupakan salah satu mata pelajaran yang wajib diberikan pada pendidikan tingkat dasar (SD/MI). 
Matematika adalah salah satu ilmu yang sangat penting dalam dan untuk hidup kita. Banyak hal di sekitar kita yang selalu berhubungan dengan Matematika. Mencari nomor rumah seseorang, menelepon, jual beli barang, menukar uang, mengukur jarak dan waktu, dan masih banyak lagi. Karena ilmu ini sedemikian penting, maka konsep dasar matematika yang benar yang diajarkan kepada seorang anak haruslah benar dan kuat. Paling tidak hitungan dasar yang melibatkan penjumlahan, pengurangan, perkalian, dan pembagian harus dikuasai dengan sempurna. Setiap orang, siapapun dia, pasti bersentuhan dengan salah satu konsep di atas dalam kesehariannya.

Matematika merupakan salah satu mata pelajaran disekolah-sekolah dan harus untuk dipahami karena sering dimanfaatkan dalam kehidupan sehari-hari. Matematika membantu manusia dalam memahami dan menguasai permasalahan sosial, ekonomi dan alam. Seluruh segi kehidupan manusia dari yang sederhana sampai yang paling kompleks dapat dimasuki oleh matematika. Karena konsep matematika yang bersifat abstrak penerapannya dalam kehidupan sehari-hari dapat ditinjau dari berbagai sudut.

Kegunaan matematika dalam penerapan kehidupan manusia menjadikan sekolah sebagai salah satu lembaga pendidikan formal yang mampu mengajarkan matematika. Matematika di sekolah hendaknya di definisikan dengan menggunakan definisi matematika sekolah. Definisi ini tampak lebih mudah dipahami dan lebih ramah bagi siswa. Dalam Kurikulum 2004 disebutkan "Matematika adalah studi tentang bahan-bahan yang memiliki objek abstrak dan dibangun melalui proses penalaran deduktif, bahwa konsep kebenaran diperoleh sebagai konsekuensi logis dari kebenaran diterima sebelumnya bahwa hubungan antara konsepkonsep matematika dalam yang sangat kuat dan jelas“. Sedangkan dalam Kurikulum 2006 dijelaskan bahwa Matematika adalah ilmu universal yang mendasari perkembangan teknologi modern, memiliki peran penting dalam berbagai disiplin ilmu dan mempromosikan kekuatan pikiran manusia.
Dalam Kamus Besar Bahasa Indonesia, Matematika diartikan sebagai ilmu bilangan, hubungan antar bilangan dan prosedur operasional yang digunakan untuk penyelesaian masalah mengenai bilangan (Ariesandi S, 2007: 1). Dalam Kamus Matematika ( Kerami D, 2002: 158), matematika diartikan sebagai pengkajian logis mengenai bentuk, susunan besaran, konsepkonsep yang berkaitan dan seringkali dikelompokkan dalam 3 bidang yaitu geometri, analisis dan aljabar.

Russel dalam bukunya Uno dan Kuadrat (Uno H, 2009: 108) mendefinisikan bahwa yang dimaksud matematika sebagai suatu bidang studi yang dimulai dari pengkajian bagian-bagian yang sangat dikenal menuju ke arah yang tidak dikenal. Arah yang dikenal tersusun baik (konstruktif) secara bertahap menuju arah yang rumit (kompleks) dari bilangan bulat ke bilangan pecahan, bilangan riil ke bilangan kompleks, dari penjumlahan dan perkalian ke differensial dan integral, dan menuju matematika yang lebih tinggi.

Menurut (Isjoni, 2012: 14), pembelajaran adalah sesuatu yang dilakukan oleh siswa, bukan dibuat untuk siswa. Pembelajaran pada dasarnya merupakan upaya pendidik untuk membantu peserta didik melakukan kegiatan belajar. Tujuan pembelajaran adalah terwujudnya efisiensi dan fektifitas kegiatan belajar yang dilakukan peserta didik.

Pembelajaran matematika di sekolah dapat menggunakan pola pikir deduktif maupun induktif, hal ini harus disesuaikan dengan topik bahasan dan daya intelektual siswa. Secara kriteria umum, biasanya siswa di SD/MI menggunakan pendekatan induktif lebih dahulu karena hal ini dapat memungkinkan siswa menangkap pengertian yang dimaksud (Abdul H, 2009: 72).

Dari berbagai pendapat diatas, dapat disimpulkan bahwa pembelajaran matematika adalah suatu proses pengalaman belajar peserta didik melalui serangkaian kegiatan yang terencana sehingga peserta didik memperoleh kompetensi tentang materi yang dipelajari.

Penelitian tindakan kelas yang terkait pembelajaran matematika yang peneliti 
lakukan mengacu pada batasan-batasan pembelajaran matematika terutama pada tingkat Sekolah Dasar. Dan disesuaikan dengan tahap pola pikir siswa ditingkat SD/MI yang usianya masih berkisar antara 6-12 tahun.

1. Tujuan Pembelajaran Matematika.

Tujuan Kurikulum 2013 yang diterapkan oleh Kemendikbud tertuang pada Permendikbud No. 69 Tahun 2013 Tentang Kerangka Dasar Dan Struktur Kurikulum Sekolah Menengah Atas/Madrasah Aliyah) yang berbunyi:

"Tujuan Kurikulum 2013 adalah mempersiapkan manusia Indonesia agar memiliki kemampuan hidup sebagai pribadi dan warga Negara yang beriman, produktif, kreatif, inovatif, dan afektif serta mampu berkontribusi pada kehidupan bermasyarakat, berbangsa,bernegara, dan peradaban dunia."

Dalam tujuan kurikulum 2013, siswa dituntut untuk berpikir lebih kreatif, inovatif, cepat dan tanggap dan selain itu dalam kurikulum 2013 siswa dilatih untuk menumbuhkan keberanian dalam dirinya. Siswa akan dilatih kemampuan berlogika dalam memecahkan suatu permasalahan. Dalam kurikulum 2013 ini juga diberikan atau dimasukkan unsur-unsur kehidupan bermasyarakat, berbangsa,dan bernegara serta unsur keagamaan untuk membentuk siswa yang berkarakter.

1. Ruang Lingkup Pembelajaran Matematika Adapun ruang lingkup pembelajaran matematika, meliputi :
a. Bilangan
b. Geometri dan pengukuran
c. Pengolahan Data

2. Kompetensi Dasar Mata Pelajaran Matematika

Dalam penelitian ini peneliti memfokuskan pada materi yang masuk dalam ruang lingkup geometri dan pengukuran, dengan Kompetensi Dasar menaksir keliling dan luas lingkaran serta menggunakannya untuk menyelesaikan masalah.

Adapun kompetensi yang ingin dikembangkan yaitu pada kompetensi dasar menaksir keliling dan luas lingkaran serta menggunakannya untuk menyelesaikan masalah.
3. Definisi Lingkaran

Pengertian Lingkaran: Apa itu Lingkaran? Lingkaran_adalah himpunan semua titik di bidang datar yang berjarak sama dari suatu titik tetap di bidang tersebut. Titik tetap lingkaran itu dinamakan pusat lingkaran, sedangkan jarak dari suatu titik pada lingkaran ke titik pusat dinamakan jari-jari lingkaran. Dalam pengertian yang lain, kita dapat menyatakan bahwa lingkaran adalah sebuah garis lengkung yang bertemu kedua ujungnya, sedangkan semua titik sama jauh letaknya dari sebuah titik tertentu. Titik ini dinamakan pusat lingkaran, jarak dari suatu titik pada lingkaran ke titik pusat dinamakan jari-jari lingkaran dan garis lengkung yang bertemu kedua ujungnya itu dinamakan keliling lingkaran. Daerah yang dibatasi oleh lingkaran disebut bidang lingkaran.

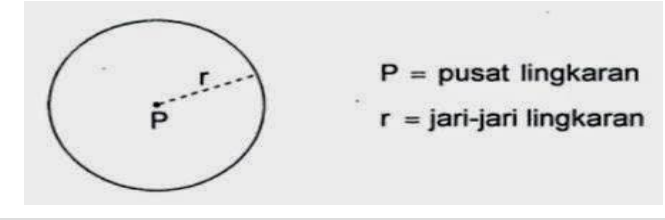

Gambar 2.1

Bagian-bagian Lingkaran

Bagian-bagian lingkaran pada umumnya terdiri dari:

a. Jari-jari Lingkaran : adalah ruas garis yang menghubungkan suatu titik pada lingkaran dengan titik pusatnya. Jarijaring lingkaran juga dapat diartikan sebagai jarak suatu titik pada lingkaran dengan titik pusatnya. Jari-jari lingkaran disimbolkan dengan $r$ atau $R$.

b. Tali Busur : adalah ruas garis yang menghubungkan dua titik pada lingkaran.

c. Diameter Lingkaran : adalah garis tengah lingkaran yang membagi lingkaran menjadi dua bidang, disimbolkan dengan $d$ atau $D$. Diameter adalah dua kali jari-jari lingkaran.

d. Apotema Lingkaran : adalah ruas garis yang ditarik dari titik pusat suatu lingkaran tegak lurus pada sebuah tali busur. Jadi, apotema berarti jarak titik pusat lingkaran dengan tali busurnya. 
e. Anak Panah Lingkaran : ruas garis yang perpanjangan apotema sampai pada busur lingkaran.

f. Busur Lingkaran : adalah bagian dari keliling lingkaran.

g. Juring atau sektor Lingkaran : adalah daerah di dalam lingkaran yang dibatasi oleh dua jari-jari lingkaran dan busur lingkaran dihadapan sudut pusat yang dibentuk oleh kedua jari-jarinya.

h. Tembereng : adalah daerah lingkaran yang dibatasi oleh busur lingkaran dan tali busurnya.

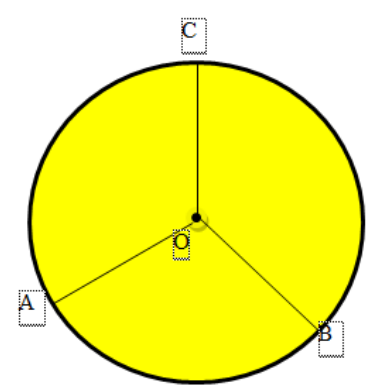

Gambar 2.2

Unsur-unsur Lingkaran

Perhatikan gambar lingkaran di atas !

Sebuah lingkaran mempunyai beberapa unsur, diantaranya jari - jari dan pusat lingkaran.

O merupakan titik pusat.

OA, OB , dan OC adalah jari - jari .

Jari - jari $(r)$ pada lingkaran memiliki panjang yang sama. Sehingga, $\mathrm{OA}=\mathrm{OB}=\mathrm{OC}$.

Lingkaran adalah tempat kedudukan titik - titik (himpunan titik) yang jaraknya terhadap satu titik tertentu adalah sama ( konstan ). Titik tertentu disebut pusat lingkaran,dan jarak konstan disebut jari - jari lingkaran.

Pada kesempatan ini penulis mengkhususkan pada kompetensi dasar menaksir keliling dan luas lingkaran serta menggunakannya untuk meyelesaikan masalah. Keliling lingkaran adalah jarak dari suatu titik pada lingkaran dalam satu putaran hingga kembali ke titik semula. Sedangkan luas lingkaran adalah daerah di dalam lingkaran yang dibatasi oleh keliling lingkaran. Asal usul cara mencari rumus luas lingkaran dapat dilakukan dengan cara menentukan rumus luas lingkaran. Lakukanlah kegiatan berikut ini.
1. Buatlah sebuah lingkaran pada karton putih dengan panjang diameter $10 \mathrm{~cm}$.

2. Bagilah lingkaran tersebut menjadi dua bagian, berdasarkan garis diameter lingkaran. Berilah warna pada salah satu bagian.

3. Bagilah kembali tiap bagian menjadi juring-juring dengan sudut $20^{\circ}$, sehingga lingkaran tersebut terbagi menjadi 18 bagian yang sama besar.

4. Bagilah kembali salah satu bagian juring menjadi dua buah juring dengan ukuran sudut $10^{\circ}$.

5. Kemudian potonglah lingkaran tersebut berdasarkan juring-juring yang telah kamu buat, dan susunlah seperti yang tampak pada gambar di bawah ini.

6. Setelah kamu susun, coba amati susunan lingkaran tersebut, apakah bentuknya menyerupai persegi panjang? Jika ya, apakah ukuran panjang dan lebarnya berhubungan dengan keliling lingkaran dan jari-jari lingkaran?

Rumus Luas Lingkaran

Dari kegiatan di atas, tahukah kamu, apa yang terjadi jika juring-juring yang dibuat sudutnya diperkecil? Jawabannya adalah bentuknya akan menyerupai persegi panjang. Maka, dapat dinyatakan bahwa:

Luas lingkaran $=$ luas persegi panjang yang tersusun $\quad=$ panjang $\times$ lebar $=1 / 2 \times$ keliling lingkaran $\times$ jari-jari lingkaran $=1 / 2 \times 2 \pi \mathrm{r} \times \mathrm{r}=\pi \mathrm{r}^{2}$ Karena $r=1 / 2 \mathrm{~d}$, maka rumus di atas dapat dinyatakan juga sebagai berikut. Luas lingkaran $=\pi(1 / 2 \mathrm{~d}) 2=1 / 4 \pi \mathrm{d}^{2}$

4. Karakteristik materi pembelajaran Matematika

Karakteristik matematika menurut Nesher (Hamzah B,2009: 109) terletak pada kekhususannya dalam mengkomunikasikan ide matematika melalui bahasa numerik. Dengan bahasa numerik tersebut, memungkinkan sesorang dapat melakukan pengukuran secara kuantitatif. Sedangkan sifat kekuantitatifan dari matematika tersebut, dapat memberikan kemudahan bagi seseorang dalam menyikapi suatu masalah. Itulah sebabnya matematika selalu memberikan jawaban yang lebih bersifat eksak dalam memecahkan 
masaalah. Selain itu matematika juga memiliki konsep struktural dan hubungan-hubungan yang banyak menggunakan simbol. Berdasarkan definisi matematika, ciri - ciri khas matematika, yang membedakannya dari mata pelajaran lain, sebagai berikut:

1. Objek pembicaraannya adalah abstrak. Sebagai contoh, konsep lingkaran sebagai tempat kedudukan titik - titik yang berjarak sama terhadap satu titik tertentu: hanya dapat dibayangkan dalam pikiran.Untuk sampai ke pemahaman itu, biasanya dapat diberi contoh dengan cincin, roda, dan sebagainya.

2. Pembahasannya mengandalkan nalar. Informasi awal berupa pengertian atau pernyataan di buat seminimal mungkin, kemudian di tunjukan kebenarannya dengan kata nalar yang logis.

3. Pengertian atau pernyataan dalam matematika diberikan berjenjang sangat konsisten. Contohnya jumlah besar sudut segitiga sama dengan $180^{\circ}$ dapat terima karena menerima pernyataan bahwa besar sudut lurus $180^{\circ}$.

4. Matematika melibatkan perhitungan dan pengerjaan ( operasi ) yang aturannya disusun sesuai dengan tata nalar.

5. Matematika dapat dialihgunakan dalam berbagai aspek ilmu maupun dalam kehidupan sehari - hari sehingga disebut pelayan ilmu dan teknologi.

Sehingga pembelajaran matematika adalah pembelajaran yang memiliki sifat atau karakteristik abstrak, karena berkaitan dengan konsep - konsep, dalil dan theorem.

\section{KESIMPULAN}

Berdasarkan penjelasan dalam pembahasan di atas, maka dapat menyimpulkan beberapa hal sebagai berikut:

1. Secara garis besar epistemologi positivisme sebagai berikut yaitu: (1) penekanan pada metode ilmiah, (2) mendasarkan sesuatu pengetahuan atas prinsip verifikasi, (3) penolakan terhadap metafisika, dan sebagainya.

2. Dengan adanya epistemologi positivisme maka mempunyai kelebihan diantaranya dan yang paling terpenting adalah kemajuan di bidang sains dan teknologi. Dan penggunaannya di masyarakat sangat luas terutama untuk penelitian sosial. Metode penelitian di masyarakat lebih dikenal dengan-metode survei".

3. Terdapat kelemahan-kelemahan ataupun kritik terhadapnya analisis biologik yang ditransformasikan ke dalam analisis sosial dinilai sebagai akar terpuruknya nilai-nilai spiritual dan bahkan nilai-nilai kemanusiaan. Hal ini dikarenakan manusia tereduksi ke dalam pengertian fisikbiologik. Akibat dari ketidakpercayaannya terhadap sesuatu yang tidak dapat diuji kebenarannya, maka faham ini akan mengakibatkan banyaknya manusia yang nantinya tidak percaya kepada Tuhan.

\section{SARAN}

Berdasarkan kesimpulan dan implikasi di atas, maka peneliti mengajukan saran sebagai berikut:

1. Kepada Kepala Madrasah

Selalu memantau pengembangan perangkat pembelajaran filsafat melalui epistemologi positivisme dalam memahami konsep menghitung keliling dan luas lingkaran.

2. Kepada Guru

Harus selalu kreatif dalam mengembangkan perangkat pembelajaran filsafat melalui epistemologi positivisme dalam memahami konsep menghitung keliling dan luas lingkaran

3. Kepada Peserta Didik

Hendaknya peserta didik jauh lebih tertarik dengan perangkat pembelajaran matematika tentang pemahaman konsep menghitung keliling dan luas lingkaran.

\section{UCAPAN TERIMA KASIH}

Penulis mengucapkan terimakasih kepada rekan-reakan dosen di lingkungan Program Studi Pendidikan Guru Madrasah Ibtidaiyah Pascasarjana, IAIN Purwokerto atas dukungannya dalam menyelesaikan penelitian ini. Penulis juga berterimakasih kepada pihakpihak yang telah mendukung penelitian ini.

\section{DAFTAR PUSTAKA}


Abdul Halim Fathoni. Matematika Hakekat dan Logika, (Ar Ruzz, Jogjakarta), 2009 hal 72

Ariesandi Setyono, Mathemagics: Cara Jenius Belajar Matematika,(Jakarta: Gramedia pustaka Utama, 2007), hal. 1

Asmoro Akhmadi, Filsafat Umum (Cet. IV; Jakarta: Raja Grafindo Persada, 2001). Bernard Deltgauw, Sejarah Ringkas Filsafat Barat, terj. Soejono Soemargono (Yogyakarta: Tiara Wacana, 1992).

Harri Hamersma, Tokoh-Tokoh Filsafat Barat Modern (Cet. V; Jakarta: Gramedia Pustaka Utama, 1992).

Harun Hadiwijono, Sari Sejarah Filsafat Barat 2 (Cet. IX; Yokyakarta: Penerbit Kanisius, 1999).

Isjoni, Pembelajaran Kooperatif Meningkatkan Kecerdasan

Komunikasi Antar Peserta Didik, (Pustaka Pelajar, Yogyakarta), 2012 hal 14

Kerami Djati dan Cormentyna Sitangga, Kamus Matematika, (Depdiknas, Balai Pustaka, Jakarta), 2002 hal 158

Koento Wibisono, Arti Perkembangan menurut Positivisme Comte (Cet. II; Yogyakarta: Gadjah Mada University Press, 1996).

Mudlor Achmad. Ilmu dan Keingin Tahu, Epistemologi dalam Filsafat (Cet. I; Bandung: Trigenda Karya, 1994).

Rizal Mustansyir dan Misnal Munir, Filsafat Ilmu, (Yogyakarta : Pustaka Pelajar, 2001), Cet. 1, h. 1-2

Uno Hamzah dan Masri Kuadrat. Mengelola kecerdasan dalam pembelajaran (sebuah konsep pembelajaran berbasis kecerdasan), (PT Bumi Aksara, Jakarta). 2009 hal 108

W. Poespoprodjo dan Ek. T. Gilarso, Logika Imu Menalar (Cet. I; Bandung: Pustaka Grafika. 1999).

W.Poespoprodjo, Logika Scientifika Pengantar Dialektika dan Ilmu (Cet. I; Bandung: Pustaka Grafika, 1999). 